DEPARTMENT OF THE INTFRIOR

UNITED STATES GEOLOGICAL SURVEY

MAP SHOWING MINERAL RESOURCES OF THE SAN FRANCISCO

BAY REGION, CALIFORNIA-PRESENT AVAILABILITY AND PLANNING FOR THE FUTURE

By Edgar H. Bailey and Deborah R. Harden

Work done in cooperation with

U.S. DEPARTMENT OF HOUSING AND URBAN DEVELOPMENT

OFFICE OI: POLICY DEVELOPMENT AND RESEARCH 


\title{
MAP SHOWING MINERAL RESOURCES OF THE SAN FRANCISCO BAY REGION, CALIFORNIA-PRESENT AVAILABILITY AND PLANNING FOR THE FUTURE ${ }^{1}$
}

\author{
By Edgar H. Bailey and Deborah R. Harden
}

\section{INTRODUCTION}

In little more than a century, the predominantly rural, agricultural area around San Francisco Bay has become a great metropolis that includes several major cities and hundreds of square miles of ever-expanding peripheral residential suburbs. The population has increased from less than 100,000 people in the 1850's to more than 5 million in the early 1970's. The quantity of mineral resources needed to support the expanded population has gone up at an even greater rate because with an increase in the standard of living, each individual requires more. Fortunately, within the bay region the mineral commodities needed in large amounts for construction and industrial use could be found and extracted locally, hydrocarbon and geothermal energy resources were available, and some mineral products, such as salines and mercury, were even abundant enough to be exported. However, mineral resources, being nonrenewable, can be mined to exhaustion, or urban expansion can make them unavailable by covering them with streets and buildings or rendering their use undesirable because of environmental considerations. Will there be enough of the mineral resources still available to maintain growth, or just to support the necessary renewal, of the bay region metropolis 10 years from now - or what about 100 years from now?

A favorable response to the questions of future availability of resources lies in long-range planning leading to the optimum use of the mineral-bearing land, and this report was prepared especially to provide background data for planners and land-use decisionmakers on whom this future availability depends. On the basis of this, the report and accompanying map (1) indicate what and where the mineral resources in the bay area are, (2) examine future bay area requirements in light of present uses and projected growth, and (3) suggest steps that might be taken to assure that the identified resources will be available when needed.

A consideration beyond availability is that of the desirability of utilizing a resource in spite of environmental disruption that may accompany its extraction. The removal of many mineral resources may be accompanied by dirt, noise, earth vibrations, unsightly pits or dumps, or contamination of water or air. Much of this

\footnotetext{
1 Jointly supported by the U.S. Geological Survey and the Department of Housing and Urban Development as part of a program to develop earth-science information in a form applicable to land-use planning and decisionmaking.
}

can be either totally avoided or minimized by proper planning and regulation. It is not the purpose of this report to recommend for or against the utilization of local resources, but we do feel an obligation to point out potential deleterious environmental effects and possible actions that can be taken to minimize or eliminate them.

This report and map are based on in-depth summaries of the occurrence, resource, use, methods of mining and extraction, environmental considerations, and projections of future requirement for 26 individual mineral products prepared by commodity experts on the staff of the California Division of Mines and Geology. Their basic compilation and this report make up part of a comprehensive study of the geologic environment of the San Francisco Bay Region being done by the U.S. Geological Survey with support of the U.S. Department of Housing and Urban Development. Because the 26 mineral commodity summaries are exhaustive and lengthy, they are not being published with this report but are being made available as a document placed in open file of the U.S. Geological Survey. This 175-page document may be consulted at the following locations: U.S. Geological Survey libraries-Room 4A100, 12201 Sunrise Valley Drive, Reston, Va. 22092; Building 25, Federal Center, Denver, Colo. 80225; 345 Middlefield Road, Menlo Park, Calif. 94025; Public Inquiries Offices504 Custom House, 555 Battery Street, San Francisco, Calif. 94111; 7638 Federal Building, 300 N. Los Angeles Street, Los Angeles, Calif. 90012; and offices of the California Division of Mines and Geology-118 Resources Building, 1416 9th Street, Sacramento, Calif. 95814; Ferry Building, San Francisco, Calif. 94111; and State Office Building, 107 South Broadway, Los Angeles,Calif. 90012.

\section{MINERAL RESOURCE UTILIZATION}

PAST AND PRESENT

The nine counties of the San Francisco Bay Region have an area of almost 7,000 square miles, and in a general way they form a semicircular area centered on San Francisco and extending outward for a distance of 75 miles. Within this area live about 5 million people (1970), most of whom dwell on less than 5 percent of the land that comprises the relatively flat alluvial plains bordering the bay. Much of the rest of the land is mountainous, reaching altitudes of 3,845 feet at Mount Diablo 


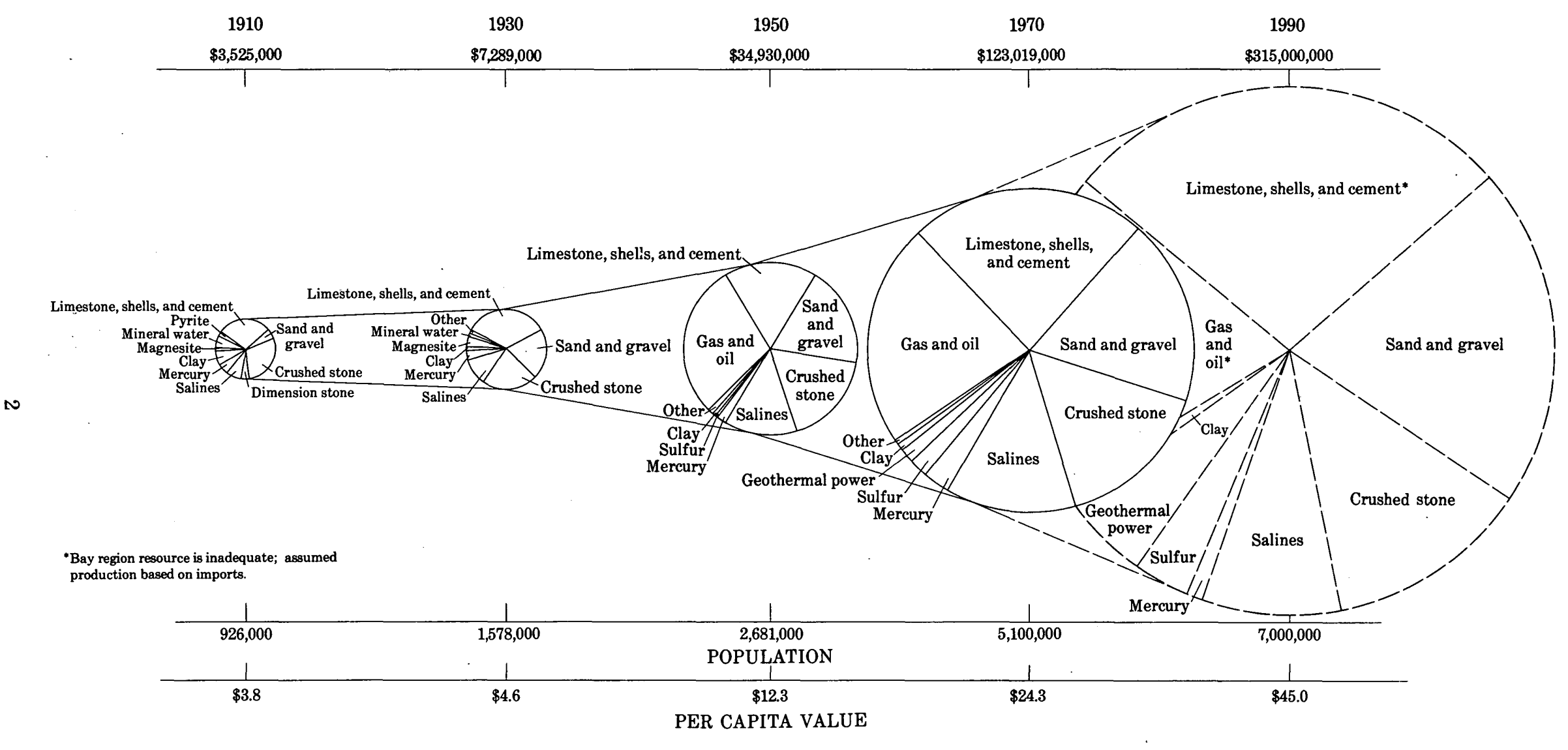

FIGURE 1.-Past and projected mineral production, San Francisco Bay Region. 
and 4,344 feet at Mount St. Helena, but between the ranges are intermountain valleys that are intensively used for both agriculture and residences. The mineral sources are chiefly in the populated plains or valleys rather than in the mountains, but despite this, few inhabitants of the bay area are more than vaguely aware that there has been any production of mineral resources in the area. Yet, the total value of mineral products extracted in the bay area by 1970 exceeds $\$ 2,000,000,000$ and in the past few years has annually exceeded $\$ 100,000,000$. Although a few commodities account for most of the value, at least 26 individual mineral commodities have been recovered in sufficient amounts to be considered in this report. Most mineral products have been used locally, fulfilling a need for low-cost construction materials and a supply of energy, as well as providing the basis for employment for thousands of people.

Trends in mineral production in response to the huge increase in population in the bay area are shown graphically in figure 1 . This chart is based on the dollar value of the mineral products at 20-year intervals, utilizing years selected as representative of normal peacetime periods. The figure shows clearly that the major mineral resources recovered in the bay area are (1) construction materials, such as limestone and oyster shells (used in manufacture of cement), sand and gravel, and crushed stone; (2) energy sources such as gas, oil, and geothermal power; and (3) salines. Together these mineral commodities account for more than 90 percent of the value of the bay area mineral products, and it is also significant that virtually all were used within the bay area. In contrast, most of the mercury recovered from bay area ores has been exported.

Figure 1 also indicates that with the urbanization of the bay area, which received its greatest impetus in the early 1940's, the dollar value of local production has doubled every decade. Although a part of this can be attributed to rising unit value, owing to inflation, more than half the increase is a result of greater local requirements for the growing population. Also, as is indicated by the figures at the base of the diagram, per capita mineral requirements, in terms of dollar value, have doubled every 20 years.

Through the past 60 years the change in relative amounts of different mineral commodities produced in the bay area is remarkably small, though a few commodities provide notable exceptions (fig. 1). The overall production pattern for 1970 is much like that of 1950 , but geothermal power, first produced in 1960, has become significant. Similarly, sulfur, recovered in large amounts as a valuable byproduct of oil refining in 1970 , was formerly (until about 1950) dissipated into the atmosphere, constituting an undesirable pollutant. On the other hand, magnesite, though once important, has not been mined since 1961 and has been of little importance since World War II. Mineral water, another relatively minor commodity, also appears now to be proportionally in much less demand than 50 years ago, but reliable data for the more recent decades are not available. The commodities with major production, account- ing for 90 percent of the total, although being used in rapidly increasing amounts, are all tied to the urban economy and population growth so that the production of each increases uniformly with the others. We can expect similar trends to continue, but only as long as resources are available within the bay area.

\section{FUTURE MINERAL UTILIZATION}

The quantity of mineral products that will be recovered in the bay area in the next two decades depends upon: (1) the population, (2) per capita mineral and energy needs, (3) availability of the mineral resources, and (4) policies adopted by regulatory agencies. This section discusses future production in terms of future needs, assuming that currently available resources will still be available and used when needed. Consideration of environmental impact, desirability of continued production, and steps that can be taken to assure proper mineral utilization are deferred until a later section.

Estimates of future mineral requirements are closely linked with population projections, and for the bay area there currently is considerable variation in projections made by different groups. It seems certain that there will be as many people in the bay area in 1990 as there are now (1974), and projections of population growth indicating an increase of less than 50 percent to about 7 million seem reasonable. If we accept the projection, and if mineral needs for buildings, roads, energy, and so on are locally supplied at the same per capita rate as now, the 1990 mineral industry will have an annual production value of about $\$ 200$ million. However, as the per capita mineral production has historically increased at a rate that doubled every 20 years, one may project an annual production for 1990 closer to $\$ 350$ million. Owing to the expected depletion of some mineral commodities, this high level of production is not likely to be reached, but the magnitude of the figures indicates the importance of a local mineral industry to the economy of the area. It also emphasizes the need to plan for development of the San Francisco Bay Region in such a fashion that the mineral resources needed in the future will be available in amounts that are several times as large as are presently being used.

The mineral products to be recovered in the future will probably come chiefly from the sources now known and being used, though the possibility of new discoveries always exists. Figure 2 shows, for each of the bay area counties, the location, magnitude, and prospect for utilization for each of 26 mineral commodities that have been recovered locally. In addition, figure 3 shows an areawide summation of past production and outlook for future production by commodity.

Continued or renewed production of many of the bay area mineral resources, especially in the large amounts to be required in the future, offers potential environmental problems. These differ according to the commodity involved, the site of extraction, the method of extraction, and the processing necessary to yield a usable 


\begin{tabular}{|c|c|c|c|c|c|c|c|c|c|}
\hline Commodity & Alameda & Contra Costa & Marin & Napa & San Francisco & San Mateo & Santa Clara & Solano & Sonoma \\
\hline Asbestos & $t$ & 0 & & + & & & & & \\
\hline Chromite & + & 0 & 0 & + & 0 & 0 & + & 0 & + \\
\hline Clay & + & $\square$ & $\mathbf{\square}$ & + & 0 & 0 & + & $\square$ & + \\
\hline Coal & 0 & 0 & . & & & & & & \\
\hline Copper & 0 & 0 & 0 & 0 & & & 0 & & 0 \\
\hline Diatomite & & $\mathbf{a}$ & & $\square$ & & & & & $\square$ \\
\hline $\begin{array}{l}\text { Expansible } \\
\text { shale }\end{array}$ & $\mathbf{\square}$ & $\mathbf{n}$ & $\mathbf{\square}$ & D & 0 & 0 & 0 & 0 & 0 \\
\hline Gemstones & 0 & 0 & + & + & + & + & + & 0 & + \\
\hline $\begin{array}{c}\text { Geothermal } \\
\text { resources }\end{array}$ & & & & + & & & & & 口 \\
\hline $\begin{array}{l}\text { Limestone } \\
\text { and shells }\end{array}$ & 4 & $\square$ & 0 & 0 & & ג & $x$ & 0 & 0 \\
\hline Magnesite & 0 & & & 0 & & & 0 & & 0 \\
\hline Manganese & + & 0 & 0 & 0 & & & + & & 0 \\
\hline Mercury & 0 & + & $\square$ & $\square$ & 0 & 0 & $\mathbf{a}$ & + & $\square$ \\
\hline $\begin{array}{r}\text { Mineral } \\
\text { water }\end{array}$ & & + & + & $\mathbf{a}$ & & $\mathbf{\square}$ & $\mathbf{\square}$ & & $\mathbf{\square}$ \\
\hline Oil and gas & 0 & 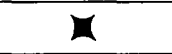 & 0 & 0 & & $t$ & 0 & $x$ & 0 \\
\hline Peat & & $\square$ & & & & & 0 & $\square$ & \\
\hline Pumice & & + & & 口 & 0 & & & + & + \\
\hline Pyrite & 0 & & & & & & & & \\
\hline Salines & $\mathbf{\square}$ & & + & $\mathbf{a}$ & & $\mathbf{\square}$ & $\mathbf{\square}$ & $\mathbf{\square}$ & \\
\hline $\begin{array}{c}\text { Sand and } \\
\text { gravel }\end{array}$ & 口 & 0 & 0 & च & $\mathbf{\square}$ & 0 & a & $\square$ & $\square$ \\
\hline $\begin{array}{l}\text { Sands, } \\
\text { specialty }\end{array}$ & 0 & $\square$ & & & 0 & 0 & & & \\
\hline Silver & & & & + & & & & & \\
\hline $\begin{array}{l}\text { Stone, crushed } \\
\text { and broken }\end{array}$ & ש & $\boldsymbol{\square}$ & $\mathbf{0}$ & $\boldsymbol{\square}$ & 0 & $\mathbf{a}$ & $\square$ & $\square$ & $\mathbf{\square}$ \\
\hline $\begin{array}{l}\text { Stone, } \\
\text { dimension }\end{array}$ & 0 & 0 & $\mathbf{\square}$ & 口 & 0 & 0 & 0 & $\mathbf{D}$ & $\mathbf{\square}$ \\
\hline $\begin{array}{l}\text { Stone, } \\
\text { ornamental }\end{array}$ & & & + & & & & & 口 & \\
\hline $\begin{array}{l}\text { Sulfur, } \\
\text { byproduct }\end{array}$ & & 口 & & & & & & & \\
\hline
\end{tabular}

\section{EXPLANATION}

Occurrence, not likely to be used

+ Small resource, or usable only at high price

$\square \quad$ Significant resource not being used but likely to be used within next 20 years

a Significant resource being used

- Significant resource being used but likely to be exhausted, seriously depleted, or uneconomic in 20 years

FIGURE 2.-Mineral resources of the San Francisco Bay Region by county. 


\begin{tabular}{|c|c|c|c|c|c|c|c|c|}
\hline Commodity & $\begin{array}{c}\text { Approximate } \\
\text { total value } \\
\text { to } 1973, \\
\text { in dollars }\end{array}$ & $\begin{array}{l}\text { Approximate } \\
\text { value } \\
\text { recent year, } \\
\text { in dollars }\end{array}$ & $\begin{array}{l}\text { Bay } \\
\text { region } \\
\text { impor- } \\
\text { tance }\end{array}$ & $\begin{array}{c}\text { Statewide } \\
\text { or } \\
\text { national } \\
\text { importance }^{2}\end{array}$ & $\begin{array}{l}\text { Availa- } \\
\text { bility }^{3}\end{array}$ & Outlook $^{4}$ & $\begin{array}{l}\text { Kind of } \\
\text { operation }\end{array}$ & $\begin{array}{c}\text { Potential } \\
\text { environmental } \\
\text { effects }{ }^{6}\end{array}$ \\
\hline Asbestos & 600,000 & 0 & - & - & + & - & $\mathbf{Q}$ & $\mathrm{S}, \mathrm{N}$ \\
\hline Chromite & 520,000 & 0 & - & - & \pm & - & $\mathbf{Q}$ & $\mathrm{S}, \mathrm{N}, \mathrm{W}$ \\
\hline Clay & $19,000,000$ & $1,000,000$ & + & - & + & + & $\mathbf{Q}$ & $\mathrm{S}, \mathrm{W}$ \\
\hline Coal & $16,000,000$ & 0 & - & - & \pm & - & $\mathbf{Q}$ & $\mathrm{S}, \mathrm{W}$ \\
\hline Copper & 60,000 & 0 & - & - & - & - & $\mathrm{UM}, \mathrm{BP}$ & $\mathbf{w}$ \\
\hline Diatomite & $1,000,000$ & 200,000 & + & - & + & + & $\mathbf{Q}$ & $\mathrm{S}, \mathrm{N}, \mathrm{A}$ \\
\hline $\begin{array}{l}\text { Expansible } \\
\text { shale }\end{array}$ & $40,000,000$ & 400,000 & + & - & + & + & $\mathbf{Q}$ & $\mathrm{S}, \mathrm{N}, \mathrm{A}$ \\
\hline Gemstones & 11,000 & $(0 ?)$ & \pm & - & + & + & C & None \\
\hline $\begin{array}{l}\text { Geothermal } \\
\text { resources }\end{array}$ & $5,000,000$ & $1,500,000$ & + & + & + & + & W & $\mathrm{W}, \mathrm{A}, \mathrm{N}$ \\
\hline $\begin{array}{l}\text { Limestone } \\
\text { and } \\
\text { shells }\end{array}$ & $\begin{array}{c}500,000,000 \\
\text { (includes } \\
\text { cement) }\end{array}$ & $\begin{array}{c}30,000,000 \\
\text { (includes } \\
\text { cement) }\end{array}$ & + & - & + & + & $\mathrm{Q}, \mathrm{SM}$ & $A, S, N$ \\
\hline Magnesite & $10,000,000$ & 0 & - & - & + & - & UM, Q & $\mathrm{S}, \mathrm{N}$ \\
\hline Manganese & 620,000 & 0 & - & - & + & - & UM, Q & $\mathrm{S}, \mathrm{A}, \mathrm{N}$ \\
\hline Mercury & $110,000,000$ & $3,200,000$ & + & + & \pm & \pm & UM, Q & $\mathrm{S}, \mathrm{A}, \mathrm{N}, \mathrm{W}$ \\
\hline $\begin{array}{r}\text { Mineral } \\
\text { water }\end{array}$ & $5,000,000(?)$ & $?$ & - & - & + & \pm & W & None \\
\hline Peat & $1,000,000(?)$ & 100,000 & - & - & + & + & Q, SM & $\mathbf{S}$ \\
\hline Pumice & $1,200,000$ & 4,000 & - & - & + & - & $\mathbf{Q}$ & S, A \\
\hline Pyrite & $2,000,000$ & 0 & - & - & \pm & - & UM & $\mathrm{S}, \mathrm{A}, \mathrm{W}$ \\
\hline Salines & $290,000,000$ & $16,000,000$ & + & + & + & + & W & $\mathbf{S}$ \\
\hline $\begin{array}{l}\text { Sand and } \\
\text { gravel }\end{array}$ & $370,000,000$ & $22,500,000$ & + & - & \pm & + & Q, SM & $\mathrm{S}, \mathrm{A}, \mathrm{N}$ \\
\hline $\begin{array}{l}\text { Sand, } \\
\text { specialty }\end{array}$ & 200,000 & 53,000 & \pm & - & + & + & Q,SM & $\mathbf{S}$ \\
\hline $\begin{array}{l}\text { Silver and } \\
\text { gold }\end{array}$ & $1,600,000$ & 0 . & \pm & - & \pm & \pm & UM & $\mathrm{S}, \mathrm{N}, \mathrm{W}$ \\
\hline $\begin{array}{l}\text { Stone, crushed } \\
\text { and broken }\end{array}$ & $273,000,000$ & $18,700,000$ & + & - & + & + & $\mathbf{Q}$ & $\mathrm{S}, \mathbf{N}, \mathbf{A}$ \\
\hline $\begin{array}{l}\text { Stone, } \\
\text { dimension }\end{array}$ & $4,600,000$ & 45,000 & - & - & + & \pm & $\mathbf{Q}$ & $\mathrm{S}, \mathrm{N}$ \\
\hline $\begin{array}{l}\text { Stone, } \\
\text { ornamental }\end{array}$ & 150,000 & $?$ & \pm & - & \pm & \pm & $\mathbf{Q}$ & $\mathbf{S}$ \\
\hline Oil and gas & $420,000,000$ & $26,500,000$ & + & + & \pm & + & W & S, W, A \\
\hline $\begin{array}{l}\text { Sulfur, } \\
\text { byproduct }\end{array}$ & $25,000,000$ & $2,500,000$ & + & - & + & + & BP & None \\
\hline $\begin{array}{r}+ \text { Shoul } \\
\pm \text { Could } \\
- \text { Unne } \\
+ \text { Suppl } \\
- \text { None. }\end{array}$ & $\begin{array}{l}\text { nine if possible. } \\
\text { nport or get alon } \\
\text { sary or unavailal } \\
\text { ther parts of Un }\end{array}$ & $\begin{array}{l}\text { without. } \\
\text { le. } \\
\text { ed States. }\end{array}$ & & \multicolumn{5}{|c|}{$\begin{array}{ll}\text { JM } & \text { Underground mine. } \\
\text { SM } & \text { Quarry. } \\
\text { Wubmarine mining. } \\
\text { Well, spring, or pond. } \\
\text { SP } & \text { Collected. } \\
\text { Byproduct. }\end{array}$} \\
\hline $\begin{array}{l} \pm \text { Wide } \\
\pm \text { Limit } \\
- \text { Unav } \\
\pm \text { Expe } \\
\pm \text { Declir } \\
- \text { Will t }\end{array}$ & $\begin{array}{l}\text { ead or readily av } \\
\text { supply, or availa } \\
\text { able. } \\
\text { ontinued or grea } \\
\text { g or doubtful pro } \\
\text { minate, or has te }\end{array}$ & $\begin{array}{l}\text { lilable. } \\
\text { le only at high pr } \\
\text { er exploitation. } \\
\text { duction. } \\
\text { minated. }\end{array}$ & & \multicolumn{5}{|c|}{$\begin{array}{l}\text { Surface disturbance, such as quarry or dump. } \\
\text { Air pollution. } \\
\text { Water pollution. } \\
\text { Noise. }\end{array}$} \\
\hline
\end{tabular}

FIGURE 3.-Summary of availability and projected availability of mineral resources, San Francisco Bay Region. 
product. For each commodity listed in figure 3, we have indicated the possible environmental disturbances of the land, water, or air that might accompany its utilization. The requirements for mineral products and the effects of obtaining them locally are summarized in the following section by groups of related mineral commodities, and for more details of environmental considerations for individual commodities the reader is referred to the separate chapters on each mineral product contained in the supplementary report that has been released in open file.

\section{CHARACTERISTICS OF RELATED MINERAL COMMODITIES}

CONSTRUCTION MATERIALS

Mineral commodities quarried in the bay region for use in the construction of buildings and roads have an annual value of more than $\$ 70$ million and account for considerably more than half the total value of mineral products produced. They are indispensable to modern society and, because of their bulk and low unit value, are generally mined as close to the point of use as possible. Included are vast quantities of sand and gravel, crushed stone, and limestone and shells used in the manufacture of cement. Also included are dimension stone and expansible shale, but these are quarried in such small amounts as to be relatively inconsequential and are not further discussed under this heading. Because the major construction products are needed in huge amounts, are mined at the surface in large quarries, and have unit value that is small as compared to transportation costs, they present similar environmental and economic problems and require the most consideration in planning.

A steady, and doubtless increasing, supply of mineral products for construction is a necessity for the continuing development and renewal of the bay region. Fortunately, suitable sand, gravel, and rock are available locally in adequate amounts, if the known sources remain accessible. By proper land-use planning they can be kept accessible, or in rare instances be made available after some other temporary utilization of the land. Whether or not they should be kept available for use will depend chiefly upon the results of balancing the increased costs that would result from obtaining these mineral products elsewhere against at least temporary on-site environmental damage. However, the large increase in cost that would result from importing these commodities makes it very likely that the residents will continue to be supplied from local sources, and it seems prudent to keep these sources available.

Some representative figures illustrate the increase in costs that would result from importing. The value of bulk construction materials, though variable, can be generalized as a little more than a dollar a ton. The cost of hauling by truck also varies depending on quantity hauled, distance, whether through city or countryside, and similar factors, but a general figure of $10 \mathrm{eper}$ ton-mile is reasonable. It thus becomes apparent that transporting sand, gravel, or rock 10-15 miles might double their cost, and bringing them from even just beyond the periphery of the bay region into San Francisco could increase their cost three times or more. Importing by ship should also be considered, but here unloading followed by truck transport also raises the cost significantly.

Sources of mineral commodities are generally limited and fixed by both geology and local conditions. If multiple sources are available, planners have some freedom in selecting areas to be set aside for mineral extraction or to be used for other purpose, but if sources are few the choice may be only whether to use them or not. For each of the bulk commodities, sand and gravel, crushed rock, and limestone, the conditions are a little different, so each in turn is discussed briefly in the following paragraphs.

\section{Sand and gravel}

Sand and gravel usable for aggregate most commonly occur in flat valley floors where former streams have dropped their load of worn rock fragments as they emerged from the bedrock uplands. Not every sand and gravel accumulation, however, is usable, because the rock fragments in it must be physically sound, chemically nonreactive varieties. Within the bay region, every county has some suitable deposits, but sources large enough to be quarried profitably occur in only half the counties. In major deposits, large equipment can be used for quarrying and for the necessary washing and sizing, resulting in low-unit-cost production. Nevertheless, owing to haulage costs, as previously mentioned, a small operation may supply a local need more cheaply than can a remote major producer. Both large and small quarries must generally be sited on flat land that is also suitable for agriculture or even residences, and owing to their size and the character of their operation, the quarries are likely to produce environmental problems unless careful planning is done before dense urbanization of their surroundings.

In places beneath the waters of San Francisco Bay and offshore from the Golden Gate Channel are sand deposits now exploited on a limited scale but perhaps having greater potential. In most areas the sand is too muddy or too fine to be usable, but some areas readily reached by modern dredges contain coarser material. The Point Knox-Alcatraz-Presidio shoals and parts of the Golden Gate bar seem most amenable to utilization. This material is publicly owned, and its utilization has not yet caused significant environmental disruption, but large-scale extraction might result in undesirable effects.

\section{Crushed rock}

Crushed rock suitable for commercial use must be durable and strong. Such material generally is found on hillsides, commonly those with steep slopes. Quarries for crushed rock therefore are dug literally into the sides of hills and are likely to leave visible scars, in 
contrast to gravel pits, which are normally dug down into flat areas and may be largely out of view. Suitable rock sources are found in all the bay area counties, and all have produced millions of dollars worth of crushed rock. Sources of riprap blocks larger than about 3 feet, however, are sparse, and special consideration should be given to preservation of their availability. Because of the abundance of possible sources of crushed rock, and the relatively high costs of hauling, many small local quarries have been operated to fill nearby demands. Doubtless others will be needed if costs of crushed rock are to be kept low. There is really no way to hide a rock quarry, but with many potential locations available it should be possible to site rock quarries either behind small hills or in areas unsuited for residential or recreational use where the environmental impact would be minimal.

\section{Limestone}

Limestone suitable for the manufacture of cement is now quarried in only one place, in the Santa Cruz Mountains west of Cupertino, and although many other deposits are known, they all appear to be too small to warrant building a new cement plant to make use of them. This is unfortunate, as the present plant capacity of the bay area is too small to meet even the nearfuture needs. In addition to limestone deposits, the southern part of San Francisco Bay contains a reserve of oyster shells suitable for cement manufacture, but a cement plant at Redwood City Harbor that formerly utilized this resource ceased production in 1970. As the needs of the area increase, it will be necessary to import either cement or the raw material for cement, which can be brought in most economically by ship. Requests to build portside plants or to reactivate those now in existence can be expected. The utilization of the submerged shell beds, perhaps in conjunction with imports of limestone, is an alternative that may be desirable from the viewpoint of minimal environmental impact, but this needs further investigation. In addition, the potential use of limestone deposits for purposes other than cement may be considerable; for example, crushed limestone is as suitable for concrete and bituminous aggregate as some other types of rock now being used, and its calcium carbonate content makes it useful for such processes as sugar refining and neutralization of acid waste water.

\section{Environmental considerations}

Quarries from which natural materials for construction purposes are removed are generally large, some being over half a mile long, and without careful development and reconstruction they will normally form unsightly scars on the landscape. Proper planning, however, can encourage screening them from view during their operation, and more significantly in the long run, planning can often turn the resulting pits into economic or social assets after the mineral product has been removed. For example, in the Livermore area a park has been established on a former quarry site, and in Los
Gatos excavations have been converted to groundwater percolation ponds that are used as recreational lakes. In other areas, excavations have been used for sanitary solid-waste disposal. If properly planned, quarrying can be an ephemeral land use leading to the development of a permanent asset, and in some instances tax payments from the quarrying might finance such development.

During the operational phase, sand and gravel quarries can be made least noticeable by initially locating them away from the public eye if there is a choice in site selection, or they can be hidden by appropriate screening with low peripheral mounds or trees. New quarries located in undeveloped areas can be kept isolated by greenbelt or protective zoning. For rock quarries on hillsides, however, probably only natural barriers such as a shielding hill can be effective, so the initial siting of these is critical if they are to be as unobtrusive as possible.

Other environmental damage relates to the processing of these bulk commodities, but much of it can be avoided or corrected by proper planning and applied engineering. Sand and gravel must be cleaned and sized, and settling ponds, designed to avoid clogging ground water intake areas, are necessary to remove the extracted clays or fines from the discharge water. $\mathrm{Ce}$ ment plants create much dust from fine grinding, and their exhaust stacks require advanced-design precipitators to avoid spreading a mantle of white dust over the surrounding areas. Special technology is also required to avoid air pollution from kiln exhaust gases. Rock. crushers are a source of dust, but this too can be largely controlled. Considerable noise also generally accompanies bulk commodity mining and processing operations, and the transport of their products to the site of use requires heavy-truck haulage. Thus, it is evident that the use of bulk mineral commodities for construction produces environmental damage of various kinds - some of which can be eliminated, some minimized, and some of such a character that it apparently cannot be avoided.

\section{ENERGY SOURCES}

Mineral commodities used as energy sources in the bay region have an annual value of about $\$ 30$ million, or about a fourth of the value of all the area's mineral products. Most of the value is in natural gas, but some oil is recovered, and steam for geothermal production of electricity is becoming increasingly important. Coal and peat are not generally used for fuel in the bay region because they are not economically competitive with other products, but they are present in limited amounts.

Reserves of oil and gas are small and far from adequate to meet either the present or long-term energy requirements of the area. Known geothermal resources are believed to be large, and the prospects for new discoveries are good, but it seems unlikely that the energy needs of the bay region can be met without either large imports of fuel and electrical energy or use of nuclear 
reactors. Fortunately, neither the search for these natural energy commodities nor their utilization produces environmental problems that cannot be solved.

\section{Oil and gas}

Oil and gas are both sought and produced through deep wells located more or less directly above oil or gas reservoirs. In the bay region most of the reservoirs have been found in broadly folded, relatively young rocks underlying plains, valleys, or low hills. Hence, most wells are in land suitable for other uses, including homesites, and future exploratory drill holes will be located in similar areas, with the possible exception of some drilled offshore. Drilling a well causes some environmental problems, but once a well has been completed and the rig removed, the permanent wellhead installation is small and readily concealed. Both the drilling and subsequent exploitation are controlled by existing antipollution regulations of the State of California and the Federal Government. Some consideration must be given to the possibility of the adverse effects on urban development of surface subsidence and faulting caused by the extraction of oil and gas.

\section{Geothermal steam}

Geothermal steam, which is a most attractive cheap source of energy, is also sought and recovered through deep wells. The only productive steam field in the United States is at The Geysers in the northern part of the bay region. This is in a remote section of the Mayacmas Mountains, as are all the other areas in the bay region offering the greatest promise for future discoveries. This resource was not utilized until 1960, and the large energy potential of the area adjacent to The Geysers was not fully appreciated until even more recently. As this report was prepared, exploratory drilling to extend the known steam field or to find new fields was still in progress. Doubtless geothermal steam will be sought in less promising areas in the immediate future, but the chances of finding new exploitable fields elsewhere in the area appear to be quite small from a geological viewpoint.

\section{Environmental considerations}

The drilling of any kind of deep well creates a potential for disruption or contamination of aquifers, but drilling practices are regulated and closely supervised by the California Division of Oil and Gas. Generally drilling also temporarily disrupts the surface at the site. Roads must be provided for access, a drill rig must be erected, ponds for retention of drilling fluids must be dug, and storage tanks and other temporary structures are generally required. Upon completion of the well, however, the site can be restored to its original condition, or the surface may be made even more attractive and productive than formerly. If the well is successful, a pipe must be installed to lead off the gas, oil, or steam, and for oil a simple pump is also generally necessary. If unsuccessful, the well pipe can be capped and easily hidden, in some places by burial.
Oil and gas are transmitted through buried pipes, or by boat or truck, to refineries for processing. Formerly, refineries discharged considerable sulfur and other undesirable gases into the air, but now in the bay region the sulfur is profitably recovered, flammable waste gas is burned, and emissions are closely monitored by the Air Pollution Control District. Geothermal steam is transmitted by pipe to low-pressure turbine-generators, and subsequently a condensate containing most of the undesirable boron, ammonia, and hydrogen sulfide initially contained in the steam is returned to the ground through special reinjection wells. Escaping steam creates a noise problem that can be only partly controlled, but existing wells are in remote areas and few people are affected.

\section{SALINES}

About $\$ 16$ million worth of saline products are extracted annually from the seawater of San Francisco Bay through solar evaporation. Most of the value comes from the production of more than 1 million tons of ordinary salt; magnesium salts, gypsum, and bromine are also recovered. Some of the salt and most of the other products are used within the bay region, and the bulk of the excess salt is trucked or shipped to consumers in the Northwestern United States. Present capacity is great enough to meet the local needs in the immediate future, and for reasons noted below it is not likely that the productive capacity will be expanded.

The salt is recovered by evaporation of the bay water in large shallow ponds created from the marshlands bordering shallow parts of the bay. These salt ponds now cover about 35,000 acres, chiefly rimming the southern part of the bay but including some in the extreme northern part. A complete pond system consists of concentrating ponds, crystallizing ponds, bittern ponds, and salt-washing ponds.

Present production is limited by the amount of marshland available for ponds, and less than 10,000 additional acres that might be suitable remain in the San Francisco Bay borderland. However, less land is likely to be used for ponds in the future, owing to pressure of urban expansion and increasing value of the lands for real estate development, waste disposal, wildlife habitat, and recreation. The local production of salines is a source of income and fills a bay region need, but the lands may be needed more for other purposes. Salt can be imported at a price nearly competitive with local manufacture.

\section{Environmental considerations}

The conversion of marshland to salt ponds puts into mineral production land that in large part is otherwise useful as a duck hunting area or bird refuge, or important as a spawning area for fish and as an environmental modifier in the unique fashion of all marshlands. In 1972, part of the south bay area was converted into the San Francisco Bay National Wildlife Refuge and included were several thousand acres of salt ponds. This 
did not, however, result in termination of the salt-evaporation operations as they were considered to be compatible with the aims of the refuge. A potential environmental problem connected with the evaporation process results from the quantity of highly concentrated bittern that remains after the extraction of the salt. In part the bittern can be used as a source of other saline products, but at present much of it is not being used, and some of the pond area must be devoted to its storage. Disposal of the bittern is a serious, as yet unsolved, problem that could ultimately limit the use of the area for salt production.

\section{MERCURY}

Mercury mines of the bay region have yielded half of the entire U.S. production of this metal since 1850, with a value of more than $\$ 150$ million. Annual production fluctuates widely, depending on the prevailing price. When the price is high, bay region production amounts to several million dollars a year; when it is low, as it was in 1974, most of the mines are closed. Mercury differs from all other bay region mineral commodities in that most is exported to supply needs elsewhere in the United States, and whether or not it is mined is a matter of national, as well as local, concern. The known reserves are small, but there is so much additional unexplored favorable ground that the potential resource must be considered to be large.

Mercury ore has been mined in all the bay region counties except San Francisco and Alameda. Most production has come from Santa Clara County, largely from the New Almaden mine, the most productive of all mercury mines in North America. All the deposits occur in older rocks exposed in hilly or mountainous areas, but some are on hills peripheral to valleys undergoing urbanization. Two deposits have already been lost to residential development, and even the famous New Almaden mining district is in danger of being withdrawn from production because of encroaching residential subdivisions. These mines, which provide not only jobs and money, but also the mercury needed by U.S. industry, pose a particularly difficult problem for local land-use planners or county zoning boards.

\section{Environmental considerations}

Mercury is mined in both opencuts and underground workings. Opencut mining is much like quarrying for crushed rock, and it creates noise and vibration from blasting and hauling, locally some dust, and the general unsightliness of an open scar. Mining generally requires the removal of much associated unmineralized waste rock, which must be piled somewhere, consequently opencut mercury mining is likely to disturb the environment even more than rock quarrying. Underground mining produces earth vibrations from blasting and similar to opencut mining generally yields much waste rock that must be piled at the surface. Mercury ore is processed by heating in furnaces or retorts, which generally requires crushing and is therefore noisy and may be dusty. This could be done underground in subsurface mines, but by custom it is not.

A special environmental problem that relates only to these deposits is mercury pollution of either water or air. Mercury in some forms is very poisonous to humans, animals, and birds, even in very minute amounts, and severe restrictions on the amounts that can be discharged to the air or water have recently been set by the U.S. Environmental Protection Agency. The chief mercury ore mineral is a sulfide called cinnabar, which is quite insoluble in normal waters. It is doubtful that mercury mining has anywhere raised the natural mercury content of streams flowing from the areas, though the processing of the ore to recover the metal might result in stream contamination. Mercury metal, in contrast to the sulfide, can contaminate, and the drainage of water through a dump of rock that has been put through an improperly adjusted furnace could be a source of mercury pollution. Similarly, mercury in exhaust gases from an improperly operated condensing system would cause air pollution, and even ground and water pollution if in sufficient quantity to settle out, but the newly enacted EPA controls are designed to avoid these problems.

Although almost all the bay region mercury mines were closed when this report was prepared in 1974, large amounts of mercury were still required by U.S. industry, and there is no doubt the price will again reach a level where it will be profitable to return the mines to production. It is desirable to have at least some of the domestic mines producing, as this not only brings money into a local area, but more importantly it strengthens the U.S. position with respect to total reliance on foreign producers. Thus, there are strong national reasons for maintaining a domestic mercury mining industry, even though temporary environmental damage may be unavoidable. Such damage will be minimized if the mines are isolated, as some are by the nature of the occurrence of the deposits and as others can be by zoning the surrounding area as greenbelt. Possible mercury pollution of either air or water owing to mine operations presents almost no hazard today, as it is subject to control by strict regulations that are being enforced.

\section{OTHER MINERAL COMMODITIES}

The other mineral commodities formerly or presently produced in the bay region require no extended discussion because they are not likely to be utilized, are only a very local concern, or are byproducts whose recovery helps eliminate air pollution. In all cases there is no urgent need to conserve or preserve the available resource.

Several mineral products that formerly were recovered from bay region sources probably will not be mined again in the near future, chiefly because of changed economics and greater availability elsewhere. In this category are asbestos, chromite, coal, copper, magnesite, manganese, and pyrite. Chromite, magnesite, and manganese ores from the bay region were 
utilized in war periods because our normal sources of supply from overseas were not available, the Government encouraged production, and prices were high. Chromite and manganese are now stockpiled in adequate amounts, and magnesite as a source of magnesium metal or compounds has been replaced by plants extracting magnesium from seawater and dolomite. Short-fiber asbestos, once mined on a small scale in the bay region, is now being recovered in huge amounts near Coalinga, and there is little probability that a long-fiber deposit will be found locally. Pyrite, as a source of sulfuric acid, is no longer needed because the removal of sulfur from oil in the refining process to eliminate atmospheric pollution yields large amounts of both sulfuric acid and elemental sulfur.

\section{STRATEGY FOR FUTURE MINERAL UTILIZATION}

The continuing and expanding need for mineral resources in the San Francisco Bay Region cannot be doubted, nor can one doubt that within the area are available resources to meet many of the local needs. In addition, bay region resources can also contribute to filling national needs for mercury. One can question, however, whether all, or any, of these resources should be exploited, with some attendant undesirable environmental disruption; or whether the regional mineral and energy needs should be met entirely by imports, thus eliminating the possible environmental damage due to mineral exploitation. This important regional problem, whether to produce locally or import, is of great concern to regional planners, but decisions generally will not have to be made by county or city planners, whose concern is with the development of only a small part of the region. When they consider the best use of a specific mineralized area or other local resources, the choice is generally not so clear cut as simply "use or not use," but more often involves "when to use" or "if we use, what then?" Commonly an intermediate position permitting initial use of the mineral resource with subsequent use of the land for another purpose is a favored alternative. Because many planners have little firsthand experience with mineral products that would help them in making these decisions, some aspects of mineral exploitation that should be considered in the decisionmaking process are discussed below.

From a purely monetary viewpoint, entirely omitting environmental or esthetic considerations, it is desirable to utilize any mineral resource in the bay region that can be profitably recovered because use creates wealth within the area in contrast to capital outflow that results from importing. In terms of dollar return on land use, mineral extraction gives a yield that is exceeded only under unusual circumstances in limited areas. The value of the production from all the lands exploited for mineral products in California in 1965 averaged $\$ 10,000$ per acre. For more restricted areas high yields have been obtained over a period of many years; for example, in the New Almaden mercury district, less than 1,000 acres of mineralized ground has yielded nearly $\$ 100,000,000$, or roughly $\$ 100,000$ per acre. As is well known, land underlain by oil or gas can give large dollar yields from wells, and at the same time the surface can be used for farming or other productive purposes. The high yield from mineral extraction, however, is a one-time result, as mineral resources are nonrenewable, in contrast to water, timber, or agricultural resources, which with proper management can give continuing yields.

The utilization of local mineral resources, in contrast to importing, has other economic advantages. The capital it generates goes partly to provide jobs and partly to support satellite service industries, and a substantial part generally goes for tax revenue to meet other local needs. In addition, the lower cost of the locally derived product is a significant factor in promoting other industries that use this product.

Thus, purely economic considerations favor maximum use of whatever mineral resources are available and especially those closest to the need, which means closest to population centers. But, the extraction of most mineral products is accompanied by at least some undesirable environmental impact, which leads to the need for consideration of the balance between economic and environmental factors. An inviting way to escape the impact of environmental damage is to site all points of mineral exploitation back in the mountains beyond most human notice, but even this will not eliminate disturbance by heavy truck haulage of bulk commodities. Unfortunately, in the bay region this choice of quarrying only in remote mountains generally is not available, as the positions of the deposits, particularly those of the most needed bulk commodities, are fixed, and most lie in the valley area, which is also prime land for residences and agriculture. Consequently, plans for mineral use must begin with "do" versus "don't" decisions, which generally will be tentative and hinge on a study of need, economics, methods of exploitation, environmental effects, regulation required, and possible use of land after the resource is exhausted. It seems probable, however, that economics will require use of locally available resources, and well in advance of their utilization, or even the development of their sites, three aspects of land use unique to mineral production might be considered by planning and regulatory agencies. These aspects are: (1) the protection and conservation of known deposits, (2) regulation of the extractive and processing operation, and (3) reclamation and use of the site upon completion of the operation.

\section{PLANNING FOR PROTECTION AND CONSERVATION OF MINERAL RESOURCES}

To preserve the availability of mineral deposits, especially those of construction materials, in the bay region requires a series of actions in advance of extraction. First, future needs must be forecast and analyzed, and second, potential resource sites of adequate size must be identified, inventoried, classified, and ranked, unless it is readily apparent that every deposit regardless of 
size will be needed. Then, to assure future availability of resource sites, measures must be taken to protect them from other preemptive uses, although if there is no need for immediate extraction, interim temporary uses might be permitted. Consideration should be given to reserving adequate space for processing plants, access roads, and buffer zones. As mineral processing normally uses energy, high-load electrical lines also may be required. Companies holding mineral resource land will normally pursue these considerations and request appropriate governmental action, but effective protection of resources remote from urbanization may depend upon the preparation of land-use plans before requests are received from developers.

Measures to assure the protection of mineral resources are provided for by existing land-use regulations. Regional and local planning and regulatory agencies can include plan elements that provide for mineral resource preservation and use in the regional land-use plan or the General Plan required by the California Government Code 65302. Properly prepared, these plans would include forecasts and analyses of future mineral needs, development of objectives and standards, comparison and evaluation of alternative plans, selection and detailing of one of the alternative plans, and specific implementation recommendations.

In California, one useful plan element is the Open Space Element required by the California Government Code Section 65560 et seq. This element could provide for the protection of specified recreational mineral resources such as gemstones, beach sands, and mineral waters. Another plan element is the Conservation Element required by the California Government Code Section 65302(d), under which areas are preserved specifcally for mineral resources that can be economically extracted with minimum damage to the environment and existing development. This plan element should show the location, depth, areal extent, and estimated quantity of the mineral deposits. It should also consider accessibility, electric power, processing plants, market proximity, and the existing, interim, and ultimate land uses of the mineral sites.

For the implementation of such plan elements several methods are available, any of which if properly designed and enforced would protect and conserve the mineral resource until needed. These methods include zoning ordinances, special land-use regulations, or public acquisition depending upon State enabling legislation.

To permit interim use of a mineral deposit site until needed for mineral extraction, a Mineral Conservation District can be designed to permit nondevelopmenttype uses such as crops, floriculture, plant nurseries, vineyards, hay, livestock, orchards, paddocks, recreation, and parklands, all of which involve little or no construction.

Proposals for extraction of the mineral resource would require an application for, and rezoning to, a Mineral Extraction District. Any extraction or separating of mineral resources would be a conditioned use in such a district and require a special permit to which conditions of operation, reclamation, and sureties would be legally binding. Manufacturing and processing not attendant upon, or related to, the extractive and separation operations would not be permitted in the Mineral Extraction District but would require an application for, and rezoning to, a Heavy Industrial District.

\section{PLANNING FOR REGULATION OF THE EXTRACTIVE OPERATION}

Regulations to ensure minimum environmental damage during mineral extraction should be considered in advance of the operation. Environmental problems vary with the type and location of the deposit, but some to be considered are: destruction of flora and fauna, erosion, flooding, siltation of streams and lakes, disruption of drainage patterns, clogging of ground-water intake areas, other ground-water contamination, surface-water pollution, damage to roads and other property, stimulation of landslides, subsidence or faulting due to removal of fluids, noise, unsightliness, storage of toxic wastes, disposal of bittern, fires, traffic congestion, overloading of access roads, adverse effects on neighboring land values, and other losses or hazards.

Many of these problems can be prevented or mitigated by careful design and strict enforcement of performance standards, conditions, and financial sureties attached to a conditional use permit, or for publicly owned land, a public lease agreement. Performance standards for mineral extractive operations may be adopted as part of a city or county zoning ordinance or incorporated into a public lease agreement. Such performance standards may include specific controls on emissions, fire and explosive hazards, glare and heat, liquid and solid wastes, sound levels, odors, radioactivity, dust, electric disturbances, and vibrations.

In addition, the extraction can be controlled by the specific requirements of a conditional use permit or public lease agreement. For effective review the application for such a permit should include a description of the proposed operation, detailed list of equipment, machinery, and structures to be used, and source, quantity, and disposition of water. It should also include a photograph and survey of the site showing existing topography by contours, and vegetation, access roads, other proposed roads, and excavation depths. And, if complete, it contains a statement regarding the proposed reclamation program. Some of the conditions that may be attached to a conditional use permit, depending upon the type and location of extractive operation, include hours of operation, lighting control, fencing, traffic routes, parking requirements, spoil storage, landscaping, settling ponds, buffer zones, commencement and completion dates, deed restrictions, increased setbacks, filing of engineering maps, energy conversion, type of construction, special pollution-control equipment, and the stripping and stockpiling of topsoil, nutrient-rich rocks, or marginal ore.

Reclamation of the site and financial sureties to 
assure such reclamation can also be conditions attached to the conditional use permit or a public lease agreement. Although this subject is discussed below, it must be considered before an operation commences and be included as a part of the conditional use permit.

\section{PLANNING FOR RECLAMATION OF THE SITE}

After land has been exploited for its mineral resources, its mineral potential has normally been completely removed. In the absence of any program for rehabilitation, after mineral extraction is completed, land containing either a mine or quarry will have become unsightly with open holes, piles of waste, and abandoned processing plants, and it may also include safety hazards such as open tunnels or unstable ground. With sufficient funds, an exploited area can be returned to a condition approximating its original appearance, but generally this is too costly to be practical and alternate better uses are available, especially if they have been anticipated and planned for.

Quarries made during the removal of sand and gravel need not be just holes to be filled in, as they can provide the basis for other desirable land use. With planned restructuring, a quarry area might be converted to a park, golf course, stadium, or safe target practice range. Multiple uses also are possible; for example, in Los Gatos lakes that are primarily ground-water percolation areas are used as duck and boating ponds, forming the focal area for a much-used civic park. Even sequential uses are available; for example, quarries have been used as solid-waste disposal areas until filled and then converted to park or agricultural land. It is thus obvious that quarries resulting from extraction of sand and gravel can be regarded as useful excavations rather than as eyesores, if imagination is used in the original planning. Rock quarries that are generally sited on hillsides are more of a problem, but a few might be given over to those who wish practice areas for their hobby of rock climbing.

Underground mine areas, which contain dangerous holes and piles of waste rock, are not readily converted to any other use, but fortunately most will be in mountainous areas containing land of minimal value. Locally, a few tunnels are now being used for bombproof storage of valuable records, for raising mushrooms, for aging wine, or as low-yield water tunnels to supply a ranch or two. Nevertheless, the need for abandoned mines for these purposes is limited. For safety most open mines can be sealed at the portal or shaft collar when no longer in use.

The most readily available means for ensuring the design and enforcement of a site reclamation program is to provide for this in a conditional use permit or public land agreement. This can specify the method and degree of land restoration or modification required, and it should lead to converting the land to continuing usefulness after the exhaustion of the mineral resource.

For successful reclamation, not only are a plan and regulatory conditions needed, but also strict enforce- ment is required. One method to ensure compliance with the conditions of the use permit is that of requiring of the applicant to file, before the permit is granted, financial sureties adequate for the regulatory agency or unit of government to repair any damage and to complete the restoration if the applicant defaults. Fees adequate to provide for inspection, engineering, legal, and administration costs may also be required of the applicant.

Depending upon the type, size, and duration of the extractive operation, staged operations and reclamation may be required. Staging reduces the sureties required, allows modification of the conditions and reclamation program as experience is gained, and ensures that the first stage is restored before the second stage is permitted to begin. Staging the reclamation can also result in major savings, as it is much less expensive to perform earthmoving work concurrently with the extraction while heavy equipment is on the site.

\section{SELECTED REFERENCES}

Selected published materials that discuss environmental problems and suggested solutions related to mineral extractive operations are listed below for interested citizens and local officials.

Ahearn, V. P., Jr., 1964, Land use planning and the sand and gravel producer: Washington, D.C., Natl. Sand and Gravel Assoc., 30 p.

American Society of Planning Officials, 1961, Land use control in the surface extraction of minerals: Inf. Rept. 153, pt. 1,18 p.

Bauer, A. M., 1965, Simultaneous excavation and rehabilitation of sand and gravel sites: Washington, D.C., Natl. Sand and Gravel Assoc., 60 p.

California Council on Intergovernmental Relations, 1973, Guidelines for local general plans, State of California: California Council Intergovt. Relations, $91 \mathrm{p}$.

California Division of Mines and Geology, 1972, Hazardous excavations: California Geol., p. 247-257.

1973, Urban geology, master phase for California: Phase 1: California Div. Mines and Geology, p. 1-1-A-26.

Coates, D. R., ed., 1972, Environmental science workbook: New York State Univ. Pubs. in Geomorphology, $412 \mathrm{p}$.

Council on Environmental Quality, 1973, The President's 1973 environmental program: Washington, U.S. Govt. Printing Office, $585 \mathrm{p}$.

Evans, J. R., and Davis, F. F., 1973, Mining, waste discharge requirements, and water quality: California Geol., p. 231-239.

Garvey, J. R., Chn., 1973, Research and applied technology symposium on mine-land reclamation, 1st, Pittsburgh, Pa.: Natl. Coal Assoc., 355 p.

Rickert, D. A., and Spieker, A. M., 1971, Real-estate lakes; U.S. Geol. Survey Circ. 601-G, 19 p.

U.S. Dept. of the Interior, 1967, Surface mining and our environment: Washington, U.S. Govt. Printing Office, $124 \mathrm{p}$. 